\title{
PENGARUH DESAIN POST INSTAGRAM TERHADAP MINAT PEMBELIAN PRODUK UMKM KEDAI KOPI DI KABUPATEN SLEMAN
}

\author{
Dian Prajarini ${ }^{1}$, Dwisanto Sayogo ${ }^{2}$ \\ 1,2Desain Komunikasi Visual, Sekolah Tinggi Seni Rupa dan Desain Visi Indonesia \\ dianpraja@stsrdvisi.ac.id ${ }^{1}$, dwisayogo@stsrdvisi.ac.id ${ }^{2}$
}

\begin{abstract}
Abstrak
Media sosial yang bisa digunakan untuk pemasaran produk adalah Instagram. Dua jenis konten Instagram yaitu foto dan video menarik orang untuk melakukan tindakan like, comment dan share. Perkembangan UMKM Kopi dengan banyaknya usaha yang sama, memerlukan promosi yang baik untuk menarik minat konsumen. Melalui Instagram, UMKM Kopi bisa memasarkan produk mereka. Desain post Instagram memberi pengaruh tersendiri terhadap pelanggan maupun follower mereka salah satunya minat pembelian. Penggunaan foto, ilustrasi, gambar, teks iklan, bahkan video dalam konten Instagram digunakan untuk menarik konsumen. Penelitian ini bertujuan untuk mengetahui dan menganalisis pengaruh desain post Instagram terhadap minat pembelian produk UMKM Kopi di Kabupaten Sleman. Metode penelitian yang digunakan adalah metode penelitian kuantitatif dengan analisis data menggunakan regresi linier sederhana. Hasil dari penelitian menyatakan bahwa terdapat pengaruh desain feed instagram terhadap minat pembelian produk UMKM Kopi di Kabupaten Sleman. Gambar, warna, copy writing dan call to action merupakan komponen desain post Instagram yang memberikan kontribusi terhadap minat pembelian adalah sebesar $29,4 \%$ dan sisanya $70,6 \%$ minat pembelian dipengaruhi oleh faktor lain yang tidak diteliti dalam penelitian ini.
\end{abstract}

Kata Kunci: desain, post, Instagram, UMKM, kopi, Sleman

\begin{abstract}
Instagram is the Social media that can be used for product marketing. Two types of Instagram content that attracted people to like, comment, and share were photos and videos. The development of coffee MSMEs with the same number of businesses requires good promotion to attract consumer interest. Through Instagram, coffee MSMEs can market their products. Instagram feed design has a distinct influence on their customers and followers, one of them is purchase interest. This study aims to determine and analyze the effect of Instagram feed design on the purchase interest of MSMEs Coffee products in the Sleman. The research method used is quantitative methods with data analysis using simple linear regression. The results indicate that there is an effect of Instagram feed design on the interest in purchasing coffee MSME products in Sleman. Image, color, copywriting, and call to action are feed-design components that contribute $29.4 \%$ of purchase interest, and the remaining $70.6 \%$ of purchase interest influenced by other factors not examined in this study.
\end{abstract}

Keywords: design, post, Instagram, MSMEs, coffee, Sleman 


\section{PENDAHULUAN}

Media sosial saat ini, bisa dikatakan menjadi salah satu kebutuhan pokok masyarakat khususnya di Indonesia. Melalui media sosial masyarakat mendapatkan berbagai macam informasi baik informasi positif maupun negatif dengan cepat di manapun dan kapanpun. Hal ini berarti media sosial merupakan media penyebaran informasi yang sangat cepat karena langsung menyasar secara personal pada jejaring pertemanan yang dimiliki dengan adanya fitur sharing. Selain sebagai media informasi, media sosial juga menjadi media komunikasi, hal ini dikarenakan adanya fitur komentar atau comment sebagai sarana tanya jawab bahkan klarifikasi atas informasi yang disajikan antara pemilik akun dan pengikutnya maupun antara pengikut satu dengan pengikut yang lainnya. Salah satu kegunaan positif media sosial dalam penyebaran informasi adalah sebagai media promosi untuk memasarkan produk. Pemasaran produk dalam hal ini terbagi dalam dua kategori yaitu pemasaran berbayar (iklan bersponsor) pada akun bisnis dan pemasaran hanya dengan mengunggah foto pada akun pribadi. Salah satu media sosial yang digunakan untuk pemasaran produk adalah Instagram. Melalui kemampuannya berbagi foto dan video, Instagram bisa digunakan untuk memasarkan produk maupun jasa meskipun tanpa akun bisnis.

Instagram agaknya melihat kelebihan manusia yang menyukai gambar visual. Hal ini ditandai dengan dua jenis konten yang disajikan dalam Instagram yaitu foto/gambar dan video. Dua jenis konten ini akan menarik orang untuk melakukan tindakan like, comment dan share. Daya tarik fitur Instagram ini ditanggap apik oleh penggunanya untuk dijadikan salah satu media pemasaran produk dan jasa mereka. Mulai dari produsen dengan brand terkenal bahkan sampai pada industri kecil rumahan atau usaha mikro kecil menengah (UMKM).

Usaha Mikro Kecil Menengah (UMKM) merupakan salah satu penggerak perekonomian daerah, bahkan bangsa Indonesia. Kabupaten Sleman, Daerah Istimewa Yogyakarta (DIY) sampai tahun 2018 memiliki 36.000 UMKM yang ada di 86 desa bertumbuh dengan pesat dengan dibuktikan besaran omset per tahun rata-rata 300 juta rupiah (Aprita, 2018). Salah satu sektor atau bidang usaha dalam UMKM adalah industri kuliner. Industri kuliner merupakan sesuatu yang sangat dekat masyarakat baik itu industri makanan maupun minuman. UMKM jenis minuman yang sedang berkembang dan terus bertambah jumlahnya di DIY adalah kedai kopi (UMKM Kopi). Minum kopi saat ini merupakan budaya yang sedang tren di kalangan anak muda. Meminum kopi sambil bercengkerama atau mengerjakan tugas menjadi sebuah rutinitas baru. Kabupaten Sleman, dengan banyaknya universitas yang secara administratif berada di wilayahnya membuat UMKM Kopi berkembang pesat.

Perkembangan UMKM Kopi dengan banyaknya usaha yang sama, memerlukan promosi yang baik untuk menarik minat konsumen. Melalui media sosial, UMKM Kopi ini memasarkan produk mereka. Desain post Instagram memberi pengaruh tersendiri terhadap pelanggan maupun follower mereka. Penggunaan foto, ilustrasi, gambar, teks iklan, bahkan video dalam konten Instagram digunakan untuk menarik konsumen. Berdasarkan penjabaran sebelumnya, maka perlu dilakukan penelitian pengaruh desain 
post Instagram terhadap minat pembelian produk UMKM Kopi di Kabupaten Sleman, dengan hipotesis bahwa desain post Instagram mempengaruhi minat pembelian produk UMKM Kopi di Kabupaten Sleman.

Instagram merupakan salah satu media sosial berbagi foto. Melalui post beridentitas serta konsisten, maka proses branding menjadi lebih komunikatif dan informatif (Hananto, 2019). Pada post Instagram, hal yang menjadi fokus utama user saat pertama kali adalah gambar yang ada dalam post Instagram dibandingkan dengan membaca caption gambar (Sari and Lidia, 2019). Kajian penggunaan Instagram telah dilakukan oleh beberapa peneliti di antaranya pengaruh promosi kafe Sobaholic di Instagram terhadap minat berkunjung (Anggraeni, 2018), dalam simpulannya terdapat pengaruh promosi melalui Instagram terhadap minat berkunjung Kafe Sobaholic. Paparan dari responden mengatakan bahwa pesan promosi yang menarik serta penggunaan gambar makanan dan minuman yang menggugah selera menjadi salah satu faktornya. Peran Media Sosial Instagram Dalam Menarik Minat berkunjung Mahasiswa Ilmu Komunikasi Universitas Mulawarman Di Wisata Ladang Budaya Tenggarong memberikan kesimpulan bahwa konten Instagram mempengaruhi kepercayaan, sikap dan perilaku sehingga mahasiswa tertarik mengunjungi wisata Ladang Budaya Tenggarong (Machruf and Wibowo, 2018). Saran yang diberikan adalah perlunya peningkatan pembuatan konten.

Penelitian lain memaparkan bahwa terdapat pengaruh signifikan akun Instagram Javafoodie sebagai akun yang mereview kuliner (pihak ketiga) terhadap minat beli konsumen di Studio Kopi (Makhin, 2016). Saran dari penelitian ini adalah pengkajian lebih lanjut dengan penambahan faktor lain yang bisa mempengaruhi minat beli konsumen selain foto dan gaya penulisan caption. Sikap positif pada media sosial Instagram berpengaruh pada minat belanja melalui Instagram (Anjaskara, 2016). Ketertarikan tersebut tercermin dari adanya ketertarikan untuk mencari tahu informasi terhadap produk yang dijual dan selanjutnya melakukan pembelian produk. Variabel yang diukur adalah tampilan, teks, data, promosi.

Penelitian pada akun Instagram Smrfoodies mengemukakan bahwa terdapat pengaruh akun Instagram Smrfoodies terhadap minat beli, salah satunya adalah konten Instagram (Poorwaningsih et al., 2019). Oleh karena itu sebagai saran, konten Instagram harus memiliki kualitas yang baik serta gaya tulisan caption atau copywriting yang lebih lengkap. Media iklan instagram berpengaruh positif terhadap keputusan pembelian (Lubis and Wibowo, 2016). Konten Instagram yang meliputi kandungan pesan foto, gaya komunikasi dan kualitas informasi mempengaruhi minat berkunjung Konsumen ke Klinik Kopi (Febbyana and Anggreni, 2018).

Penelitian Pengaruh Iklan Online Melalui Instagram Terhadap Keputusan Pembelian Bagi Peningkatan Penjualan Produk Kuliner Lokal memberikan kesimpulan bahwa faktor attitude towards the advertising, ad recall dan click through rates memiliki hubungan positif terhadap keputusan pembelian (Dewi, 2018). Adapun saran yang diberikan hendaknya pelaku UKM terus membuat program dan mempromosikan produknya agar tetap diingat dan direkomendasikan oleh pembeli. Berdasarkan penelitian-penelitian 
yang dijabarkan sebelumnya, penelitian ini akan menemukan hubungan antara desain post Instagram (sub variabel layout, gambar, warna, copywriting, call to action) bisa mempengaruhi minat pembelian produk (minat eksplorasi dan minat transaksional) khususnya produk UMKM Kopi di Kabupaten Sleman.

\section{METODE PENELITIAN}

Penelitian ini menggunakan metode penelitian kuantitatif. Populasi penelitian ini adalah follower dari 5 (lima) akun Instagram kedai kopi yang mewakili UMKM Kopi yang berada di Kabupaten Sleman, Daerah Istimewa Yogyakarta. Jumlah populasi pada penelitian ini sebanyak 11.222 dengan rincian (1) Tanya Kopi, 587 follower; (2) Ethikopia Coffebay, 6.589 follower; (3) Sintesis Coffee \& Space, 2.066 follower; (4) Kopi Lhur, 647 follower dan (5) Kopi Banua, 1.333 follower

Sampel pada penelitian ini ditentukan menggunakan Rumus Slovin karena sudah diketahui jumlah populasinya (Umar, 2008) sebanyak 99 sampel. Pengambilan sampel ini juga dilakukan dengan dua pertimbangan yaitu (1) responden adalah follower dari akun Instagram kedai kopi terpilih; (2) responden pernah melakukan pembelian produk pada kedai kopi terpilih.

Penelitian ini dilakukan dengan meneliti kejadian yang telah dilakukan dengan melihat latar belakang untuk mendapatkan faktor-faktor yang mempengaruhi peristiwa atau kejadian tersebut atau dikenal dengan penelitian ex post facto (Sugiyono, 2012). Sehingga dalam penelitian ini, variabel bebas $(X)$ adalah desain post Instagram UMKM Kopi dan variabel terikat $(Y)$ adalah minat pembelian produk. Metode pengumpulan data dilakukan dengan menggunakan survei sebagai sumber data utama.

Tabel 1. Variabel Penelitian

[Sumber: Dokumentasi penulis, 2020]

\begin{tabular}{|c|c|c|}
\hline Variabel & Indikator & Komponen \\
\hline \multirow{7}{*}{$\begin{array}{c}\text { Variabel X } \\
\text { (Desain post } \\
\text { instagram) } \\
\text { (Anggraeni 2018; } \\
\text { Febbyana and } \\
\text { Anggreni 2018; } \\
\text { Poorwaningsih et } \\
\text { al. 2019) }\end{array}$} & \multirow{2}{*}{ Layout } & $\begin{array}{l}\text { Tata letak tulisan, gambar dan atau foto } \\
\text { secara keseluruhan dalam konten IG }\end{array}$ \\
\hline & & $\begin{array}{l}\text { Kombinasi simbol, ilustrasi gambar/foto } \\
\text { dan huruf yang serasi dalam konten IG }\end{array}$ \\
\hline & \multirow{5}{*}{ Gambar } & $\begin{array}{l}\text { Desain konten IG menggunakan } \\
\text { pendekatan minimalis menyajikan foto } \\
\text { produk yang bisa digunakan untuk menarik } \\
\text { perhatian konsumen dalam waktu yang } \\
\text { relatif singkat/fokus atas konten yang } \\
\text { disajikan }\end{array}$ \\
\hline & & $\begin{array}{l}\text { Konten IG akun menggunakan foto produk } \\
\text { nyata }\end{array}$ \\
\hline & & $\begin{array}{l}\text { Konten IG akun menggunakan foto produk } \\
\text { produk dan suasana nyata yang menarik }\end{array}$ \\
\hline & & $\begin{array}{l}\text { Kualitas konten gambar/foto IG memiliki } \\
\text { resolusi cukup }\end{array}$ \\
\hline & & Konten IG berupa video \\
\hline
\end{tabular}




\begin{tabular}{|c|c|c|}
\hline Variabel & Indikator & Komponen \\
\hline & \multirow[b]{3}{*}{ Warna } & $\begin{array}{l}\text { Warna teks dan warna background konten } \\
\text { IG memiliki kontras yang nyaman dibaca }\end{array}$ \\
\hline & & $\begin{array}{l}\text { Penggunaan warna secara keseluruhan } \\
\text { mencerminkan persona akun IG }\end{array}$ \\
\hline & & $\begin{array}{l}\text { Penggunaan warna yang konsisten pada } \\
\text { tiap konten IG yaitu memiliki color pallete } \\
\text { yang membuat keseluruhan konten IG } \\
\text { menjadi satu kesatuan yang } \\
\text { merepresentasikan identitas dari brand } \\
\text { tersebut }\end{array}$ \\
\hline & \multirow{3}{*}{ Copy Writing } & $\begin{array}{l}\text { Caption ditulis menggunakan bahasa yang } \\
\text { mudah dimengerti }\end{array}$ \\
\hline & & Caption ditulis sesuai dengan konten \\
\hline & & Caption memberikan informasi yang jelas \\
\hline & \multirow[b]{2}{*}{ Call to Action } & Caption bersifat mengajak \\
\hline & & $\begin{array}{l}\text { Caption menggunakan bahasa yang bersifat } \\
\text { personal (person to person) }\end{array}$ \\
\hline \multirow{5}{*}{$\begin{array}{c}\text { Variabel Y } \\
\text { (Minat } \\
\text { pembelian) } \\
\text { (Ferdinand, 2006) }\end{array}$} & \multirow{2}{*}{ Minat Eksplorasi } & $\begin{array}{l}\text { Ketertarikan untuk melihat konten post } \\
\text { yang lain }\end{array}$ \\
\hline & & $\begin{array}{l}\text { Ketertarikan untuk melihat dan membaca } \\
\text { setiap post konten yang baru }\end{array}$ \\
\hline & \multirow{3}{*}{ Minat Transaksional } & $\begin{array}{l}\text { Keinginan membeli produk setelah melihat } \\
\text { post kontennya }\end{array}$ \\
\hline & & $\begin{array}{l}\text { Tindakan mengajak orang lain membeli } \\
\text { dengan men-tag orang lain pada post akun }\end{array}$ \\
\hline & & $\begin{array}{l}\text { Membeli produk setelah melihat post } \\
\text { konten IG mendapat reaksi positif }\end{array}$ \\
\hline
\end{tabular}

Alat ukur data dalam penelitian ini menggunakan skala likert dengan 4 (empat) kategori jawaban pada setiap pertanyaan. Skala likert jenis ini digunakan agar meniadakan jawaban netral atau ragu-ragu dari responden yang memiliki arti ganda (Hadi, 1991).

Tabel 2. Tabel Skala Likert yang digunakan

[Sumber: Dokumentasi penulis, 2020]

\begin{tabular}{|c|l|c|}
\hline No & \multicolumn{1}{|c|}{ Pilihan } & Bobot \\
\hline 1 & Sangat Setuju & 4 \\
\hline 2 & Setuju & 3 \\
\hline 3 & Tidak Setuju & 2 \\
\hline 4 & Sangat Tidak Setuju & 1 \\
\hline
\end{tabular}

Instrumen penelitian diukur menggunakan pengujian validitas dan reabilitas. Pengujian hipotesis, untuk melihat adanya pengaruh variabel bebas $(\mathrm{X})$ terhadap variabel terikat (Y) menggunakan analisis dengan regresi linier sederhana. 


\section{HASIL DAN PEMBAHASAN}

\subsection{Hasil Uji Instrumen}

Pengujian validitas instrumen dengan menggunakan Pearson Correlation dengan nilai signifikan 0,05 di mana dengan $\mathrm{n}=99$, maka $r$-tabel adalah 0,195. Item instrumen dinyatakan valid apabila nilai r-hitung $>$ dari $r$-tabel. Seperti terlihat pada Tabel 3 dan Tabel 4, instrumen dikatakan valid karena nilai r-hitung > 0,195.

Tabel 3. Hasil Uji Validitas Variabel X (Desain Post IG)

[Sumber: Dokumentasi penulis, 2020]

\begin{tabular}{|l|r|r|r|}
\hline & \multicolumn{3}{|c|}{ X } \\
\cline { 2 - 4 } & Pearson Correlation & Sig. (2-tailed) & $\mathrm{N}$ \\
\hline $\mathrm{X} .1$ & .629 & .000 & 99 \\
\hline $\mathrm{X} .2$ & .604 & .000 & 99 \\
\hline $\mathrm{X} .3$ & .674 & .000 & 99 \\
\hline $\mathrm{X} .4$ & .544 & .000 & 99 \\
\hline $\mathrm{X} .5$ & .671 & .000 & 99 \\
\hline $\mathrm{X} .6$ & .637 & .000 & 99 \\
\hline $\mathrm{X} .7$ & .728 & .000 & 99 \\
\hline $\mathrm{X} .8$ & .693 & .000 & 99 \\
\hline $\mathrm{X} .9$ & .682 & .000 & 99 \\
\hline $\mathrm{X} .10$ & .724 & .000 & 99 \\
\hline $\mathrm{X} .11$ & .648 & .000 & 99 \\
\hline $\mathrm{X} .12$ & .690 & .000 & 99 \\
\hline $\mathrm{X} .13$ & .667 & .000 & 99 \\
\hline $\mathrm{X} .14$ & .637 & .000 & 99 \\
\hline $\mathrm{X} .15$ & .538 & .000 & 99 \\
\hline $\mathrm{X}$ & 1 & & 99 \\
\hline
\end{tabular}

Tabel 4. Hasil Uji Validitas Variabel Y (Minat Pembelian)

[Sumber: Dokumentasi penulis, 2020]

\begin{tabular}{|l|r|r|r|}
\hline \multirow{2}{*}{} & \multicolumn{3}{|c|}{$\mathrm{Y}$} \\
\cline { 2 - 4 } & Pearson Correlation & \multicolumn{1}{|c|}{ Sig. (2-tailed) } & $\mathrm{N}$ \\
\hline Y.1 & .742 & .000 & 99 \\
\hline Y.2 & .711 & .000 & 99 \\
\hline Y.3 & .801 & .000 & 99 \\
\hline Y.4 & .780 & .000 & 99 \\
\hline$Y .5$ & .684 & .000 & 99 \\
\hline$Y$ & 1 & & 99 \\
\hline
\end{tabular}

Hasil uji reabilitas dengan melihat nilai cronbach's alpha, di mana instrumen dinyatakan reliabel apabila nilai cronbach's alpha $>0,6$ (Ghozali 2011). Pada Tabel 5 dan Tabel 6 terlihat bahwa instrumen penelitian realibel karena semua nilai cronbach's alpha tiap item $>0,6$. 
Tabel 5. Hasil Uji Realibitas Variabel X (Desain Post IG)

[Sumber: Dokumentasi penulis, 2020]

\begin{tabular}{|l|r|r|r|r|}
\hline & $\begin{array}{c}\text { Scale Mean if Item } \\
\text { Deleted }\end{array}$ & $\begin{array}{c}\text { Scale Variance if } \\
\text { Item Deleted }\end{array}$ & $\begin{array}{c}\text { Corrected Item- } \\
\text { Total Correlation }\end{array}$ & $\begin{array}{c}\text { Cronbach's Alpha } \\
\text { if Item Deleted }\end{array}$ \\
\hline $\mathrm{X} .1$ & 45.5253 & 40.905 & .571 & .896 \\
\hline $\mathrm{X} .2$ & 45.2929 & 40.903 & .540 & .897 \\
\hline $\mathrm{X} .3$ & 45.3535 & 39.966 & .614 & .894 \\
\hline $\mathrm{X} .4$ & 45.4141 & 41.388 & .473 & .899 \\
\hline $\mathrm{X} .5$ & 45.6970 & 39.050 & .598 & .895 \\
\hline $\mathrm{X} .6$ & 45.6364 & 39.968 & .566 & .896 \\
\hline $\mathrm{X} .7$ & 45.6566 & 39.167 & .672 & .892 \\
\hline $\mathrm{X} .8$ & 45.5051 & 40.191 & .640 & .894 \\
\hline $\mathrm{X} .9$ & 45.4747 & 39.497 & .618 & .894 \\
\hline $\mathrm{X} .10$ & 45.7374 & 37.767 & .652 & .893 \\
\hline $\mathrm{X} .11$ & 45.4747 & 40.497 & .588 & .895 \\
\hline $\mathrm{X} .12$ & 45.5354 & 40.047 & .635 & .894 \\
\hline $\mathrm{X} .13$ & 45.4646 & 40.435 & .611 & .895 \\
\hline $\mathrm{X} .14$ & 45.5657 & 40.044 & .568 & .896 \\
\hline $\mathrm{X} .15$ & 45.6970 & 40.703 & .451 & .901 \\
\hline
\end{tabular}

Tabel 5. Hasil Uji Realibitas Variabel X (Desain Post IG)

[Sumber: Dokumentasi penulis, 2020]

\begin{tabular}{|l|r|r|r|r|}
\hline & $\begin{array}{c}\text { Scale Mean if Item } \\
\text { Deleted }\end{array}$ & $\begin{array}{c}\text { Scale Variance if } \\
\text { Item Deleted }\end{array}$ & $\begin{array}{c}\text { Corrected Item- } \\
\text { Total Correlation }\end{array}$ & $\begin{array}{c}\text { Cronbach's Alpha } \\
\text { if Item Deleted }\end{array}$ \\
\hline Y.1 & 11.1818 & 5.599 & .585 & .756 \\
\hline Y.2 & 11.2626 & 5.890 & .561 & .765 \\
\hline Y.3 & 11.3333 & 5.204 & .661 & .730 \\
\hline Y.4 & 11.7273 & 4.955 & .594 & .757 \\
\hline Y.5 & 11.2626 & 5.849 & .506 & .779 \\
\hline
\end{tabular}

\subsection{Hasil Analisis Data}

Analisis data dilakukan untuk melihat apakah ada pengaruh dari variabel bebas $X$ (desain post Instagram) terhadap variabel terikat $\mathrm{Y}$ (minat pembelian). Analisis data ini menggunakan uji regresi linier sederhana. Hasil uji regresi sederhana variabel desain post Instagram terhadap minat pembelian produk UMKM Kopi di Kabupaten Sleman disajikan pada Tabel 6 . 
Tabel 6. Persamaan Regresi

[Sumber: Dokumentasi penulis, 2020]

\begin{tabular}{|l|l|r|r|r|r|r|}
\hline \multicolumn{2}{|c|}{ Model } & \multicolumn{2}{|c|}{ Unstandardized Coefficients } & $\begin{array}{c}\text { Standardized } \\
\text { Coefficients }\end{array}$ & \multirow{2}{*}{$t$} & \multirow{2}{*}{ Sig. } \\
\cline { 3 - 7 } \multicolumn{2}{|c|}{} & $B$ & Std. Error & \multicolumn{1}{c|}{ Beta } & & \\
\hline \multirow{2}{*}{1} & (Constant) & .598 & .356 & & 1.681 & .096 \\
\cline { 2 - 7 } & $\mathrm{X}$ & .689 & .108 & .542 & 6.360 & .000 \\
\hline
\end{tabular}

a. Dependent Variable: $Y$

Berdasarkan Tabel 6 dapat dijelaskan diperoleh persamaan berikut:

$$
Y=0,598+0,689 X_{1}+e
$$

Keterangan:

$\mathrm{Y}=$ Minat pembelian

$\mathrm{X} \quad=$ Desain post Instagram

Adapun arti dari koefisien regresi tersebut sebagai berikut:

1) Konstanta (a) $=0,598$

Konstanta merupakan angka tanpa adanya variabel, nilai konstanta sebesar 0,598 menunjukkan bahwa nilai minat pembelian akan sebesar 0,598 tanpa dipengaruhi variabel variabel desain post Instagram.

2) Koefisien regresi $(b)=0,689$

Variabel desain post Instagram memiliki nilai koefisien regresi sebesar 0,689 . Artinya apabila desain post Instagram meningkat lebih baik satu satuan, maka akan terjadi kenaikan minat pembelian sebesar 0,689 satuan. Arah positif berarti dengan mengikuti desain post Instagram, maka minat pembelian akan semakin baik

Hipotesis dalam penelitian ini menyatakan desain post Instagram mempengaruhi minat pembelian produk UMKM Kopi di Kabupaten Sleman. Untuk membuktikan hipotesis ini adalah dengan menggunakan uji t. Berdasarkan dari hasil uji hipotesis yang dilakukan, dapat dilihat Tabel 7 yang menunjukkan bahwa desain post Instagram berpengaruh positif signifikan terhadap minat pembelian. ditunjukkan dengan nilai t hitung sebesar 6,360 yang lebih besar dari t tabel $(1,984)$ dan nilai signifikansi 0,000 yang lebih kecil dari 0,05 . Sehingga hipotesis dalam penelitian ini yang menyatakan bahwa desain post Instagram mempengaruhi minat pembelian produk UMKM Kopi di Kabupaten Sleman diterima oleh hasil penelitian empiris.

Tabel 7. Hasil Uji t

[Sumber: Dokumentasi penulis, 2020]

\begin{tabular}{|l|l|r|r|r|r|r|}
\hline \multirow{2}{*}{ Model } & \multicolumn{2}{|c|}{ Unstandardized Coefficients } & $\begin{array}{c}\text { Standardized } \\
\text { Coefficients }\end{array}$ & \multirow{2}{*}{$t$} & \multirow{2}{*}{ Sig, } \\
\cline { 3 - 5 } \multicolumn{2}{|c|}{} & $B$ & Std, Error & \multicolumn{1}{c|}{ Beta } & & \\
\hline \multirow{2}{*}{1} & (Constant) &, 598 &, 356 & & 1,681 &, 096 \\
\cline { 2 - 7 } & $\mathrm{X}$ &, 689 &, 108 &, 542 & 6,360 &, 000 \\
\hline
\end{tabular}

a, Dependent Variable: $Y$ 
Tahapan selanjutnya yaitu uji korelasi yang bertujuan untuk mengetahui apakah diantara dua atau lebih variabel terdapat hubungan, dan jika ada hubungan bagaimana arah hubungannya, serta seberapa besar (kuat) hubungan tersebut. Sedangkan koefisien determinasi digunakan untuk mengetahui kontribusi variabel independen terhadap variabel dependen.

Tabel 8. Koefisien Korelasi dan Koefisien Determinasi

[Sumber: Dokumentasi penulis, 2020]

\begin{tabular}{|l|r|r|r|r|}
\hline Model & $R$ & $R$ Square & Adjusted $R$ Square & $\begin{array}{c}\text { Std, Error of the } \\
\text { Estimate }\end{array}$ \\
\hline 1 &, $542^{\mathrm{a}}$ &, 294 &, 287 &, 48291 \\
\hline
\end{tabular}

a, Predictors: (Constant), $\mathrm{X}$

Hasil pada Tabel 8 menunjukkan nilai korelasi (R) sebesar 0,542 yang berarti bahwa tingkat hubungan antara desain post instagram dengan minat pembelian termasuk dalam kategori cukup kuat. Tabel 8 menunjukkan bahwa nilai koefisien determinasi $(R$ Square) antara variabel independen terhadap variabel dependen sebesar 0,294. Hal ini menunjukkan kontribusi desain post instagram terhadap minat pembelian sebesar $29,4 \%$ dan sisanya $70,6 \%$ minat pembelian dipengaruhi oleh faktor lain yang tidak diteliti dalam penelitian ini.

\subsection{Pembahasan}

Berdasarkan hasil penelitian diketahui bahwa terdapat pengaruh positif antara desain post Instagram terhadap minat pembelian produk UMKM Kopi di Kabupaten Sleman. Hasil analisis tersebut telah dibuktikan dengan hasil uji $t$ yang menunjukkan nilai $t$ hitung sebesar 6,360 yang lebih besar dari t tabel $(1,984)$ dan nilai signifikansi sebesar 0,000 yang lebih kecil dari 0,05 serta nilai koefisien regresi sebesar 0,689 dengan arah positif. Salah satu kegunaan positif media sosial dalam penyebaran informasi adalah sebagai media promosi untuk memasarkan produk. Salah satu media sosial yang digunakan untuk pemasaran produk adalah Instagram. Melalui kemampuannya berbagi foto dan video, Instagram bisa digunakan untuk memasarkan produk maupun jasa meskipun tanpa akun bisnis.

Hasil penelitian ini sejalan dengan penelitian yang dilakukan oleh Makhin (2016) yang memaparkan bahwa terdapat pengaruh signifikan akun Instagram Javafoodie sebagai akun yang mereview kuliner (pihak ketiga) terhadap minat beli konsumen di Studio Kopi. Hasil ini juga mendukung penelitian yang dilakukan oleh Anjaskara (2016) dalam penelitiannya menemukan bahwa sikap positif pada media sosial Instagram berpengaruh pada minat belanja melalui Instagram. Ketertarikan tersebut tercermin dari adanya ketertarikan untuk mencari tahu informasi terhadap produk yang dijual dan selanjutnya melakukan pembelian produk. Hal terlihat bahwa desain post kedai kopi sampel menggunakan foto produk nyata yang menarik (jawaban rata-rata item sebesar 3,49) seperti terlihat pada Gambar 1, Gambar 2 dan Gambar 3. 

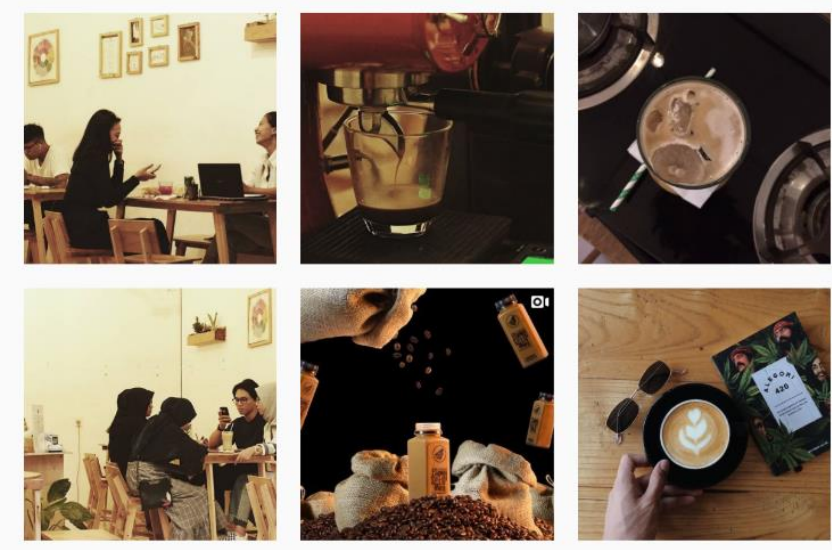

Gambar 1. Gambar Foto Produk Post IG Kopi Banua [Sumber: Instagram Kopi Banua]

Pada Gambar 1, Gambar 2 dan Gambar 3 terlihat bahwa gambar dalam post menyajikan foto produk nyata yang dijual oleh kedai kopi tersebut, baik foto produk itu sendiri maupun foto produk saat dikonsumsi oleh konsumen dengan kualitas foto yang baik.
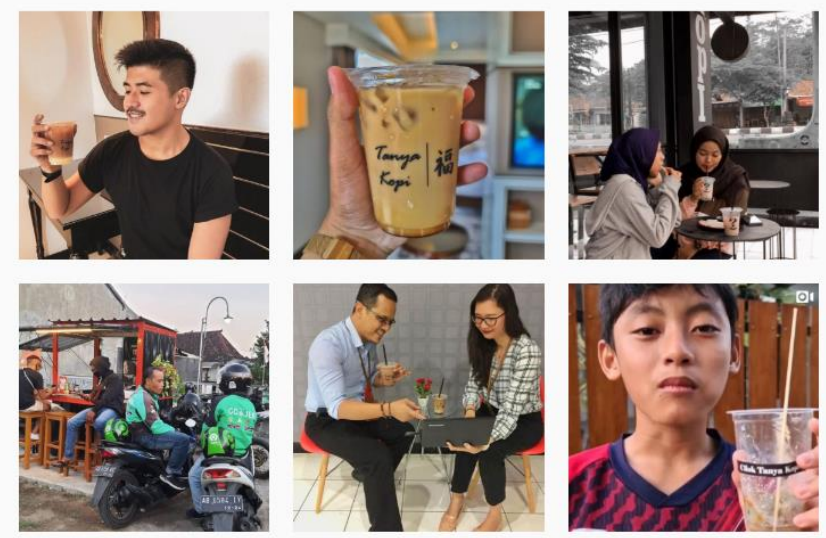

Gambar 2. Gambar Foto Produk Post IG Tanya Kopi [Sumber: Instagram Tanya Kopi]
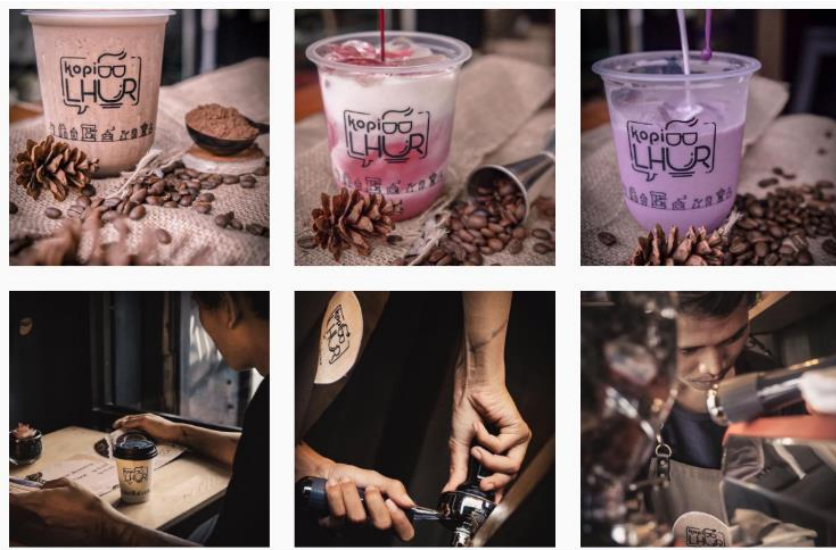

Gambar 3. Gambar Foto Produk Post IG Kopi Lhur [Sumber: Instagram Kopi Lhur] 
Penggunaan warna post yang konsisten juga digunakan oleh desain post kedai sampel seperti terlihat pada Gambar 4 dan Gambar 5. Pada Gambar 4, warna yang digunakan oleh Sintesis Kopi adalah kuning, dan keseluruhan post yang dibuat menggunakan warna kuning, sedang pada Ethikopia pada Gambar 5 menggunakan warna hitam dan coklat senada pada semua post yang dibuat. Warna yang digunakan membuat post memiliki unsur unity.
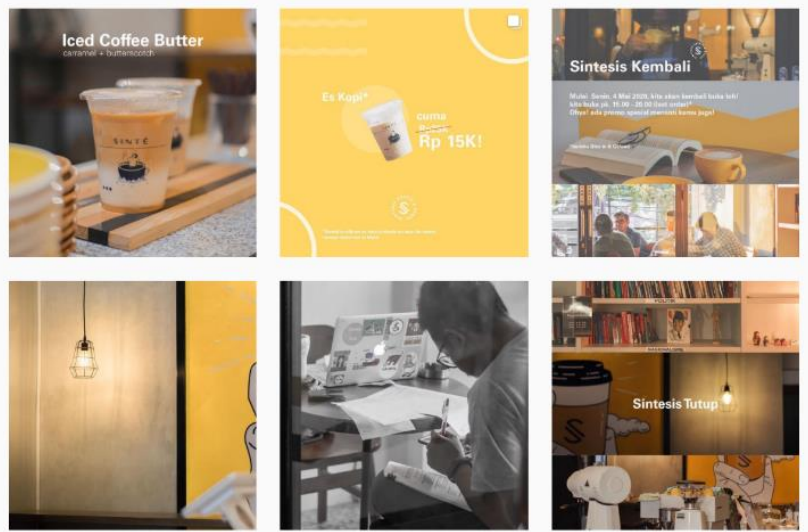

Gambar 4. Konsistensi Warna Post IG Sintesis Kopi

[Sumber: Instagram Sintesis Kopi]

Pada desain post Etikopia, terdapat beberapa desain yang menggunakan Spesimen Layout, dimana hanya terdapat teks dengan ukuran yang besar hanya berupa headline seperti terlihat pada gambar 5 sebagai point of interest, meskipun dalam hal ini white space terlihat lebih banyak namun tidak membuyarkan informasi yang disampaikan. Selain itu juga menggunakan informal balance layout namun tetap terlihat balance antara foto produk yang disajikan dengan teks yang disematkan. Pada Sintesis dalam Gambar 5 terdapat desain post yang menggunakan multi panel layout, dimana setiap panel berisi gambar yang berbeda namun tetap memiliki informasi yang sama sehingga rangkaian gambar tersebut memiliki kesatuan informasi ditunjang dengan teks penjelas di atas gambar pada bagian tengah.
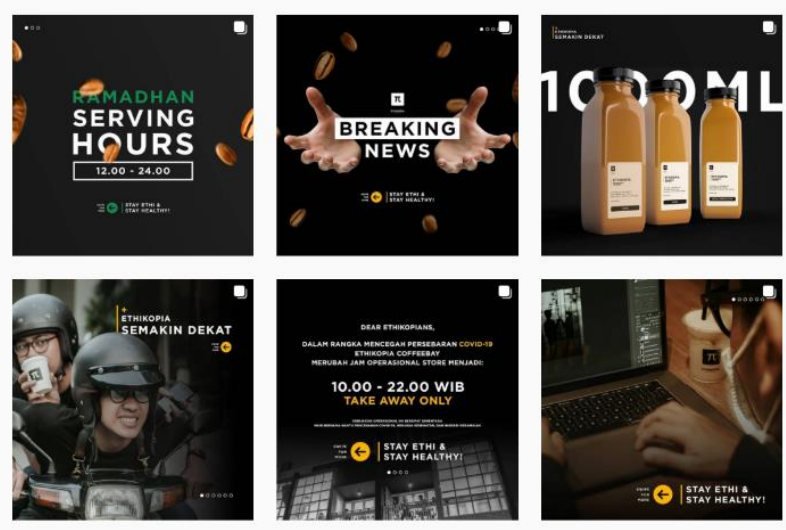

Gambar 5. Konsistensi Warna Post IG Etikopia [Sumber: Instagram Etikopia] 


\section{KESIMPULAN}

Berdasarkan hasil penelitian dan pembahasan yang sudah dijabarkan dapat ditarik kesimpulan bahwa terdapat pengaruh desain post Instagram terhadap minat pembelian produk UMKM Kopi di Kabupaten Sleman. Bahwa dalam membuat sebuah post konten Instagram perlu diperhatikan gambar, warna, copywriting dan call to action yang menjadi ciri khas sebuah brand, karena hal tersebut mempengaruhi minat beli konsumen sejalan dengan penelitian Makhin (2016) dan Anjaskara (2016). Hal ini dibuktikan dengan hasil uji $\mathrm{t}$ yang menunjukkan nilai t hitung sebesar 6,360 yang lebih besar dari t tabel $(1,984)$ dan nilai signifikansi sebesar 0,000 yang lebih kecil dari 0,05 serta nilai koefisien regresi sebesar 0,689 dengan arah positif. Besar kontribusi desain post instagram terhadap minat pembelian adalah sebesar $29,4 \%$ dan sisanya 70,6\% minat pembelian dipengaruhi oleh faktor lain yang tidak diteliti dalam penelitian ini. Oleh karena itu perlu dilakukan penelitian lanjutan untuk melihat minat beli konsumen dari pendekatan strategi konten: usergenerated content dan stories content.

\section{DAFTAR PUSTAKA}

Anggraeni, Reni Nur. (2018). Pengaruh Promosi Kafe Sobahollic Di Instagram Terhadap Minat Berkunjung (Survey Di Kalangan Follower Kafe Sobahollic Di Instagram). Banten: Universitas Sultan Ageng Tirtayasa.

Anjaskara, Dian Innes. (2016). Pengaruh Sikap Pada Media Sosial Instagram Terhadap Minat Beli Produk Kecantikan Melalui Instagram (Studi Kasus Pada Konsumen Terhadap Minat Beli Melalui Situs Instagram) Attitude. Yogyakarta: Universitas Muhammadiah Yogyakarta

Aprita, Alexander. (2018). 36 Ribu UMKM Di Sleman Berhasil Capai Omzet Rp 300 Juta Per Tahun Artikel Ini Telah Tayang Di Tribunjogja.Com Dengan Judul 36 Ribu UMKM Di Sleman Berhasil Capai Omzet Rp 300 Juta Per Tahun. [Online] $\begin{array}{llll}\text { (Updated Nov 2018) URL: } & 05 \text { N }\end{array}$ https://Jogja.Tribunnews.Com/2018/11/05/36-Ribu-Umkm-Di-Sleman-Be. TribunJogja.Com.

Dewi, Adhita Maharani. (2018). Pengaruh Iklan Online Melalui Instagram Terhadap Keputusan Pembelian Bagi Peningkatan Penjualan Produk Kuliner Lokal. Ekonika: Jurnal Ekonomi Universitas Kadiri, 3 (1), pp. 1-22. doi: 10.30737/ekonika.v3i1.78.

Febbyana, Deka Cahya, and Likha Sari Anggreni. (2018). Pengaruh Konten Instagram Terhadap Minat Berkunjung Konsumen (Studi Kuantitatif Mengenai Pengaruh Kandungan Pesan Foto, Gaya Komunikasi, Dan Kualitas Informasi Pada Akun Instagram Klinik Kopi Terhadap Minat Berkunjung Konsumen Ke Klinik Kopi Di Yogyakarta). Surakarta: Universitas Sebelas Maret.

Ferdinand, Augusty . (2006). Metode Penelitian Manajemen : Pedoman Penelitian untuk Penulisan Skripsi, Tesis, dan Disertasi IImu Manajemen. Semarang : Badan Penerbit Universitas Diponegoro.

Ghozali, Imam. (2011). Aplikasi Analisis Multivariate Dengan Program IBM SPSS 19. Edisi 5. Semarang: Badan Penerbit Universitas Diponegoro.

Hadi, Sutrisno. (1991). Analisis Butir untuk Instrumen Angket, Tes, dan Skala Nilai. Yogyakarta: FP UGM. 
Hananto, Brian Alvin. (2019). Identitas Visual Digital Brand Dalam Sosial Media Sebuah Evaluasi Konsistensi Image dan Type Karya Mahasiswa Dalam Mendesain Feed Instagram. Prosiding Seminar Nasional Desain dan Arsitektur (SENADA), 02, pp. 56-61.

Lubis, Ikhsan Bismo Hidayat, and Arif Wibowo. (2016). Pengaruh Citra Merek, Media Iklan Instagram, Pembelian Produk VANS ( Studi Kasus Pada Followers Twitter @ VHeadID ). Jurnal Manajemen Bisnis Indonesia (JMBI), 05(4), pp. 388-401.

Machruf, Bagus, and Sarwo Edy Wibowo. (2018). Peran Media Sosial Instagram Dalam Menarik Wisata Ladang Budaya Tenggarong. EJournal IImu Komunikasi, 7(1), pp. 27-41.

Makhin, Ahmad. (2016). Pengaruh Akun Instagram Javafoodie Terhadap Minat Konsumen Di Studio Kopi (Analisis Regresi Sederhana Terhadap Pengunjung Studio Kopi Di Yogyakarta). Yogyakarta: Universitas Islam Negeri Sunan Kalijaga.

Poorwaningsih, Sri Wahyuni, Finnah Fourqoniah, Annisa Wahyuni Arsyad. (2019). Pengaruh Konten Instagram @ Smrfoodies. EJournal Ilmu Komunikasi, 7(1), pp. 154-66.

Sari, Hasrini, and Anggraeni, Lidia. (2019). Peran Tipe Gambar, Tagar, Jumlah Likes Dan Informasi Harga Pada Instagram Terhadap Intensi Membeli. J@ti Undip: Jurnal Teknik Industri, 14(2), pp. 71-80.

Sugiyono. (2012). Metode Penelitian Bisnis. Bandung: Alfabeta.

Umar, Husein. (2008). Metode Penelitian Untuk Penulisan Skripsi Dan Tesis. Jakarta: RajaGrafindo Persada. 